\title{
WHAT IS PREVENTING SUCCESSFUL IMMIGRANT INTEGRATION IN THE CENTRAL AND EASTERN EUROPEAN SOCIETIES?
}

\author{
Nina MIHOLJCIC ${ }^{1}$ \\ DOI: $10.35782 / J C P P .2019 .2 .02$
}

\begin{abstract}
This article examines the factors which prevent or considerably decelerate the process of immigrant2 integration in the Central and Eastern European countries. In this research the CEE region includes countries that satisfy the two following conditions: 1 . countries that are geographically within the Central-East Europe region; 2. countries that hold a membership of the EU.3 The choice of criteria is based on common political tendencies and societal responses which are evident in selected countries as a result of the ongoing European migrant crisis. Preventing factors of immigrant integration are examined at political, social and economic levels. Both migrant perspective and the CEE countries' integration policies are examined in-depth, in order to reveal reasons for poor implementation of suggested quota system and less successful immigrant adaptation strategy in the CEE area. Since the integration of newcomers is a two-way communication, this study has to take into consideration not only countries migration policies and openness towards newcomers but also readiness of refugees and asylum seekers to integrate and adapt into new environment.
\end{abstract}

Key words: immigrant integration; Central and Eastern Europe; far-right movement; postSoviet nationalism.

\footnotetext{
${ }^{1}$ Nina Miholjcic holds a Master`s degree in Diplomacy and International Affairs. Her areas of interest include migration and refugee crisis, as well as contemporary European and post-Soviet politics. ninamih87@gmail.com

2 Immigrants, refugees and newcomers are all terms used interchangeable in the study in order to cover a broad range of migrants who want to settle in the countries of the EU from various reasons.

3 The CEE countries included in this study are Austria, Croatia, Czech Republic, Slovakia, Hungary, Poland, Romania and Bulgaria. Although Austria stands out, especially in the economic area, from other CEE countries, the author deems necessary to include the country in the research because of alarming rise of nationalism and far-right movements in the Austrian society. Political factors strongly dictate the course of the Austrian migration policy and affects settlement and migrant decisions in Austria.
} 


\section{Introduction}

Recent immense influx of immigrants into the EU territory has drawn attention to a certain divide between Western and East-Central Europe in terms of different approaches in accepting and integrating newcomers. While Western Europe has a rich experience in accommodating immigrants, as it has been an attractive destination for numerous foreigners over many centuries, CEE lags behind considerably in this regard possibly due to the almost fifty-year long Soviet closed border policy. (Horn, 2015) Unexperienced in embracing people with different cultural and religious backgrounds, the CEE region shows signs of deeply rooted xenophobic and conservative narratives which have recently turned into strong anti-immigrant national policies. Schweitzer argues that the closed doors and barbed wire policy are common in the CEE countries because of preoccupation over their own poverty and fragile economic conditions that might have hardened people`s feelings toward outsiders` distress. (Schweitzer, 2015) Indeed, many Central-East European societies still suffer from inferiority complex and struggle to achieve long-awaited economic and political stability. These societies compared to more developed Western Europe have to deal with slow economic developments and reinstalment of national and cultural identities that were to the higher or lower degree suppressed during the Soviet rule.

The analysis of migration issue is a multilayered study as migration affects political, economic, cultural and religious aspects of both transit and host societies. Immigrants decisions regarding the final destination are partially influenced by the nature of feedback coming from different areas of would-be host societies. Potential hosting countries might be afraid of accepting foreigners for various reasons. The fear driven xenophobia has different backgrounds. For instance, Cross-national measure of fear-based xenophobia research includes 5-item hierarchical scale which measures fear-based reactions to immigrants and foreigners. This study has shown multidimensional nature of xenophobia which contains personal fear (the feeling of personal threat caused by the influx of newcomers), fear of cultural change (immigrants with different cultural background are seen as a threat to existing cultural set of values), fear of identity loss (interaction with immigrants might cause dilution of national identity and purpose), fear of foreigners' disloyalty (immigrants might disrupt already established societal patterns by refusing to obey entrenched rules of the host society), and political fear (fear of losing control over the political system). (Van der Veer, Ommundsen, Yakushko Higler, 2011) Migrants might be discouraged to integrate into societies that show higher levels of xenophobia whether that kind of prejudice is based on political, economic, personal, cultural or religious motives. Integration of newcomers is a two-way relationship that requires analysis of both immigrant and would-be hosting country perspective. Successful integration implies willingness to accept and reediness to adjust. However, the $\mathrm{CEE}$ region fails to accommodate newcomers while refugees and migrants perceive the region mostly as a transit part of their long journey to the Western Europe. Lack of interest coming from both sides undermines the concept of fruitful integration in the region. This study depicts the causes of poor integration of immigrants in the CEE societies (Table.1) taking into account multidimensional nature of migration and its consequences on different areas of affected societies. 
Table no. 1. Factors that prevent successful immigrant integration

\begin{tabular}{|l|l|l|}
\hline Political Level & \multicolumn{1}{|c|}{ Immigrants } & \multicolumn{1}{c|}{ CEE Countries } \\
& $\begin{array}{l}\text { Reluctant to apply for asylum } \\
\text { in the CEE countries; these } \\
\text { countries are seen mostly as } \\
\text { transit countries and not } \\
\text { seriously considered as a final } \\
\text { destination. }\end{array}$ & $\begin{array}{l}\text { Government policies have } \\
\text { become significantly hostile } \\
\text { towards migrants; rise of } \\
\text { populist and far-right } \\
\text { movements and parties across } \\
\text { the CEE region. }\end{array}$ \\
\hline Economic Level & $\begin{array}{l}\text { Low economic incentives for } \\
\text { migrants to stay in CEE; lack } \\
\text { of job opportunities, lower } \\
\text { standard of living compared to } \\
\text { the Western Europe. }\end{array}$ & $\begin{array}{l}\text { Struggling to provide good } \\
\text { job opportunities even for } \\
\text { their own nationals; indicators } \\
\text { of less developed economies } \\
\text { in the CEE region: huge } \\
\text { emigration of both highly } \\
\text { skilled and non-skilled } \\
\text { workers to the Western } \\
\text { Europe. }\end{array}$ \\
\hline $\begin{array}{l}\text { Social Level } \\
\text { (Religion, } \\
\text { Multiculturism) }\end{array}$ & $\begin{array}{l}\text { Less free to express their } \\
\text { cultural and religious customs; } \\
\text { feeling of isolation and } \\
\text { alienation. }\end{array}$ & $\begin{array}{l}\text { Not enough exposure to } \\
\text { different cultures due to a half } \\
\text { century long Soviet } \\
\text { oppression; after the end of } \\
\text { the Cold War, CEE finally } \\
\text { had the chance to revive its } \\
\text { own religious identity and still } \\
\text { feels fragile and insecure } \\
\text { when it comes to } \\
\text { accommodating different } \\
\text { religious practices (especially } \\
\text { Islam). }\end{array}$ \\
\hline
\end{tabular}

\section{Rise of nationalism and fewer asylum applications}

Recent elections across the CEE region have shown a concerning rise of the far-right and populist parties as well as the promotion of strong anti-immigrant political narratives among regional officials. It seems that the refugee crisis has been coincided with a serious political crisis within the EU. For instance, in 2017, Austrian far-right Freedom Party of Austria (FPÖ) has managed to enter the national government by forming coalition with the center-right Austrian People's Party (ÖVP). FPO is very explicit when it comes to limiting immigration especially from the Middle East and shrinking welfare benefits to non-Austrians. (Aisch, Pearce \& Rousseau, 2017) Now this party has got a real power to exercise its populist ideology and dissuade many refugees from seeking asylum in Austria. Unfortunately, Austria is not an isolated 
example of the reviving far-right trend in CEE. Democracy in Hungary is experiencing accelerated deterioration and the ant-immigration campaign is only adding to already alarmingly increased Victor Orban`s authoritarian grip over the country. Decisively anti-immigrant, the Hungarian government built a tall fence on the border with Serbia confirming its stance as the toughest opponent to the German open door policy. (Postelnicescu, 2016) Croatia followed Hungary`s example and closed its borders for migrants as well.

Many parts of the post-socialist Europe have become a firsthand hub for the new-right ideology. Maybe the most evident signs of rising European New Right are Hungarian and Bulgarian hostile border guards who prey migrants fleeing North. (Holleran, 2018) Resurrection of the radical right has gained a lot of popularity in the CEE region recently. The Visegrad group of central European nations - Czech Republic, Hungary, Poland, and Slovakia - has not stayed immune to the rise of nationalistic and xenophobic narratives. In 2017, the anti-Islam Freedom and Direct Democracy party managed to enter the Czech parliament with almost 11 percent of votes. Moreover, reelected Czech President, Milos Zeman continues to attract attention with his strong anti-immigration statements and leanings towards Russia and China. (Muller \& Hovet, 2018) Anti-immigrant or more precisely anti-Muslim narratives have been widely used by the CEE politicians ever since the refugee crisis hit the Union in 2015. Slovakia is also actively involved in the larger CEE anti-immigration campaign. Although Slovakian neo-Nazi People`s Party underwent unexpected loss in the regional elections in 2017, still there is a harsh anti-refugee rhetoric coming from the highest political levels of the country. For instance, Slovak PM welcomed Italy`s decision to reject entrance to a couple of hundred migrants rescued in the Mediterranean. (Hungary and Slovakia back tough stance on migrants, 2018) Poland has continued to fall further into conservative, less media and judiciary free society ever since the right-wing Law and Justice Party gained incredible 39 percent of the national vote in 2015. Polish PM Kaczynski saw a great potential in the unfriendly migration policy which resulted in more restrictive entrance measures for the Middle Eastern and North African refugees. Paul Waldie argues that the official Polish anti-immigration attitude has "found a receptive audience in a country that is almost mono-ethnic and has almost no experience with multiculturalism." (Waldie, 2018) Of course, the anti-refugee rhetoric has only been added to the already nationalist-orientated Polish government. One could argue that the right-wing politicians across the CEE region have found a golden card for gaining more votes and more political power by claiming the strong anti-immigration standpoint.

Germany was very disappointed when many of the CEE countries refused to accommodate proportionally assigned number of refugees. Such lack of solidarity has deepened further political instability within the Union putting the common European security agenda and migration policy under a lot of pressure. (Postelnicescu, 2016) It is surprising that this region was the source of emigration to the Western Europe just two decades ago, but now it is showing compassion deficit towards those who are simply 
running from poverty and war. However, the reason behind such shortage in empathy might be found in different interpretation of the notion of nation. As Schweitzer notices "in eastern Europe, where borders were frequently redrawn, the nation is still widely seen as an ethnic/cultural entity rather than a political one, and cultural and ethnic homogeneity is regarded as an asset that helps to prevent the disintegration of the state." (Schweitzer, 2015) Newcomers are seen as a threatening factor that could hurt restoration of national and ethnic identities in the region. After the end of Soviet oppression many CEE countries were left at an uncertain crossroad that has intensified the fear of losing national and cultural uniqueness again. In order to prevent such unwanted events, Central and Eastern European communities rushed into rebuilding nation-states and national sovereignty, the process that is rather based on ethnicity than citizenship in this region.

Political reasons for poor immigrant integration are also visible in refugee reluctance to apply for political asylum in the CEE countries. Majority of refugees does not consider the region as an attractive destination. The number of asylum applications is much higher in the Western Europe and the first admission states (Greece, Italy) than in CEE. In 2016, almost 60 percent of overall asylum applications were submitted in Germany that is approximately 750 thousand people. (Podgorzanska, 2017) Even though 2017 recorded a drop in asylum applicants within the EU-28 by 560 thousand in comparison to 2016, still the CEE region received far less applications than the Western part of Europe, Greece and Italy. In 2018, the trend continued where the number of first-time applicants across the EU decreased by 74 thousand and the main countries of destination remained almost the same (the five top countries for asylum applicants were Germany, France, Italy, Greece and Spain). Germany was again the most attractive destination accounting almost $30 \%$ of all first-time asylum applications in 2018. (Eurostat, 2019) On the other hand, Slovakia received only 155 applications last year. Surprisingly, Hungary experienced a severe decline in number of applicants from 3,115 in 2017 to almost five times less, only 635, in the previous year. Croatia recorded 675 asylum requests and the Czech Republic had around 1,300 applicants. Submitted applications did not exceed 2,000 in Romania, while Bulgaria and Poland had approximate number of people who applied for the first time not surpassing 2,500. (Eurostat, 2019) Even though Austria was highly ranked with almost 11 thousand asylum requests in 2018, still the number of interested immigrants applying for the asylum was more than halved compared to 2017. The newly elected Austrian right-wing government with a strong anti-immigration policy most likely discouraged many to consider the country as a new settlement destination. 


\begin{tabular}{|c|c|c|c|c|c|}
\hline GEO/TIME & 2014 & 2015 & 2016 & 2017 & 2018 \\
\hline Total & 595,530 & $1,325,505$ & $1,236,285$ & 675,780 & 597,715 \\
\hline European Union 28 & 562,680 & $1,256,610$ & $1,206,045$ & 654,610 & 580,845 \\
\hline Germany & 172,945 & 441,800 & 722,265 & 198,255 & 161,885 \\
\hline France & 58,845 & 70,570 & 76,790 & 91,965 & 110,485 \\
\hline Greece & 7,585 & 11,370 & 49,875 & 56,940 & 64,975 \\
\hline Spain & 5,460 & 14,600 & 15,570 & 33,035 & 52,730 \\
\hline Italy & 63,655 & 82,830 & 121,185 & 126,550 & 49,165 \\
\hline United Kingdom & 32,120 & 39,720 & 39,240 & 34,355 & 37,290 \\
\hline Netherlands & 21,780 & 43,035 & 19,285 & 16,090 & 20,465 \\
\hline Belgium & 14,045 & 38,990 & 14,250 & 14,035 & 18,130 \\
\hline Sweden & 74,980 & 156,110 & 22,330 & 22,190 & 18,075 \\
\hline Switzerla & 21,940 & 38,060 & 25,820 & 16,615 & 13,465 \\
\hline Austria & 25,675 & 85,505 & 39,875 & 22,455 & 11,390 \\
\hline Cyprus & 1,480 & 2,105 & 2,840 & 4,475 & 7,610 \\
\hline Ireland & 1,440 & 3,270 & 2,235 & 2,910 & 3,655 \\
\hline Denmark & 14,535 & 20,825 & 6,055 & 3,125 & 3,465 \\
\hline Finland & 3,490 & 32,150 & 5,275 & 4,325 & 2,945 \\
\hline Slovenia & 355 & 260 & 1,265 & 1,435 & 2,800 \\
\hline Norway & 10,910 & 30,470 & 3,240 & 3,350 & 2,530 \\
\hline Bulgaria & 10,805 & 20,160 & 18,990 & 3,470 & 2,465 \\
\hline Poland & 5,610 & 10,255 & 9,780 & 3,005 & 2,405 \\
\hline Luxembourg & 1,030 & 2,360 & 2,065 & 2,320 & 2,225 \\
\hline Malta & 1,275 & 1,695 & 1,735 & 1,610 & 2,035 \\
\hline Romania & 1,500 & 1,225 & 1,855 & 4,700 & 1,945 \\
\hline Czechia & 905 & 1,235 & 1,200 & 1,140 & 1,350 \\
\hline Portugal & 440 & 870 & 710 & 1,015 & 1,240 \\
\hline Iceland & & 360 & 1,100 & 1,065 & 730 \\
\hline Croatia & 380 & 140 & 2,150 & 880 & 675 \\
\hline Hungary & 41,215 & 174,435 & 28,215 & 3,115 & 635 \\
\hline Lithuania & 385 & 275 & 415 & 520 & 385 \\
\hline Latvia & 365 & 330 & 345 & 355 & 175 \\
\hline Slovakia & 230 & 270 & 100 & 150 & 155 \\
\hline Liechtenstein & ( & & 75 & 145 & 145 \\
\hline Estonia & 145 & 225 & 150 & 180 & 90 \\
\hline
\end{tabular}

Source: Eurostat, Asylum and first time asylum applicants by citizenship, age and sex Annual aggregated data (rounded); updated March 3, 2019

\section{Lack of job opportunities and lower living standard}

Since the fall of the Berlin wall in 1989, the CEE region has made a slow economic progress, much less than it was hoping to accomplish after being freed from Soviet oppression and once becoming a part of prospective European economic area. EastCentral Europe did not enjoy economic benefits from the large-scale immigration during 1960-70s, as the Western part did, because it was under tight Soviet control and was left out from colonialist experience. (Schweitzer, 2018) Colonialism was very lucrative, although controversial, policy of many Western developed economies that helped boost migration and trade flows from which benefited mostly colonial countries 
of the West. Today, even though being part of the EU, the CEE region still suffers from fragile economic developments and struggles to provide prosperous job opportunities even for its own nationals. For instance, despite the fact that Poland has managed to profit from the EU membership and the Polish economy even recorded a growth of 25 percent in the period from 2004 to 2015, real income has barely seen any improvements forcing more than two million Poles to look for better work conditions in the West. (Waldie, 2018) CEE perceives newcomers rather as an economic burden than a valuable working force that can add to the national economic growth and the region is still looking for miraculous policy that could solve current economic instability and fix deprived labor market.

With the recent influx of immigrants, a widespread feeling of disappointment has overflowed CEE because many Eastern Europeans thought that joining the EU would resolve their economic crisis and that they will finally enjoy economic gains from promised tourists; instead they are left to deal with additional refugee emergency. (Krastev, 2015) In this region where many economic issues have not been resolved yet, immigrants pose a serious financial burden. Such economically insubstantial environments treat immigrants merely as receivers of support and not as the potential force that can improve the economy of the host countries in the long run. (Podgorzanska, 2017) Specific for the CEE counties is that they have to deal with their own emigration issue. While Western Europeans primarily worry over influx of immigrants and refugees, Eastern and Central Europeans are concerned with the opposite problem, which is how to prevent their own citizens from leaving. (Parikh, 2017) Although some CEE countries had tried with different anti-emigrant campaigns to prevent citizens from departing and attract those who already left, still these actions did not provide expected results.

The main indicator of Central-East Europe`s poor economic development is a concerning rate of workers ' emigration across the region. High rate of brain drain shows country`s inability to provide productive and career driven working environment for highly skilled people which push away huge economic potential to more developed markets in the West. It is estimated that around 20 million of Central and Eastern Europe's most talented workers have left since the early 1990s and many of them have settled in the Western Europe. (Parikh, 2017) However, it is not just that the highlyskilled emigration troubles CEE, non-skilled workers are also attracted by better paid job in the Western part of the EU. Due to high levels of work emigration many CEE countries suffer from serious labor shortages. For instance, over fifty percent Hungarian based companies had trouble finding personnel in the period 2016-17. (Parikh, 2017) Moreover, average net salary is much lower across CEE region compared to the wealthy economies of Denmark, Germany or Sweden. The list of average monthly net wages in the EU for 2018 shows that Bulgaria is the poorest with only $€ 457$, Romania and Hungary follow with slightly higher number but not exceeding $€ 650$ per month. Almost all other CEE countries are in the lower part of the list. The only exception is Austria occupying the sixed place with average net salary of almost 2,400 thousand euros per month. (Fischer, 2018) It does not surprise the decision of many migrants to avoid the region and pursue their dreams and new life in more productive communities. If a country cannot provide for its own citizens it is less like 
that it will deliver to newcomers like refugees and asylum seekers from the Middle East and North Africa.

Lower economic productivity, lack of job opportunities, lower standard of living compared to the Western economies are reasons that discourage many immigrants to consider the CEE countries as promising final destinations. Let us not forget that immigrants coming to the EU are mostly people in need who are either running from poverty or bloody conflicts. Those people are looking for perspective environments that can provide jobs and security. Many of them came to Europe with little or nothing and it is of essential importance for them to obtain at least minimum level of economic and social security. In most cases, newcomers want to develop their potential and exercise their talents once settled in a new environment. Jobs provide economic stability and a platform for future personal and professional development, which is why obtaining a job is so crucial for the majority of immigrants. That said, one might argue that the country with better economic conditions and employment opportunities is much more appealing to newcomers. Unfortunately, CEE still struggles to provide such conditions even to its own nationals, making itself a rather transit region for passing refugees than a seriously considered final settling destination.

\section{Unwelcomed multiculturalism and feeling of alienation}

Due to the decades of the post-war communist rule, the CEE countries were to a higher or lower level unexposed to different cultures. Exceptions are Austria and Croatia, although the latter has had a fifty-year long socialist experience of ethnic and religious suppression as one of six former republics of Yugoslavia. After the end of the Cold War, CEE finally had the chance to revive its cultural uniqueness and religious identity. However, this process of cultural and national restoration has brought other negative consequences, mainly regarding the rise of nationalistic and xenophobic sentiments where the idea of peaceful coexistence of different cultures in one place has been almost completely denied in this region. As Schweitzer notices well "there are no Belgiums or Switzerlands in eastern Europe" and the only multinational country, Czechoslovakia, had a peaceful separation just "because its internal borders reflected Czech and Slovak ethnic division." (Schweitzer, 2015) In the name of revival of strong nation-states where ethnicity plays the main role, multiculturalism and religious tolerance are sacrificed for the greater cause - ethnically and culturally homogenous countries.

In a homogenous society unaccustomed to different cultural, linguistic or religious practices, newcomers might experience a great deal of alienation and isolation. Less tolerant countries have highly exclusive mainstream cultural milieu where integration equals assimilation. Refugees from the Middle East and North Africa certainly come from very distinct cultural and religious background and to the unexposed region they might seem gravely alien. Many Central and Eastern European countries have restored their religious identities by turning them into an integral part of national and individual identities. Pew Research Center concludes that the reprisal of religion in the CEE countries, which once were controlled by atheist regimes, is outstanding although practicing religion is still at lower level in the region compared to other regions such as 
Latin America, the US, Middle East or Africa. (Religious Belief and National Belonging, 2017) However, that does not change the fact that since the collapse of the Soviet Union many Central and Eastern Europeans have become more religiously devoted. Some differences in practicing between Catholic and Orthodox Christians exist, but overall, the region has experienced unquestionable religious revival. For instance, Catholics in CEE are more religiously observant than Orthodox, they attend church more often, and pray more often. On the other hand, Orthodox Christians see religious identity as strongly connected to national identity much more than Catholics in CEE. (Religious Belief and National Belonging, 2017) While the region is trying to restitute its religious identities it still feels very fragile and unwilling to accommodate different religious practices, especially Islam.

Islamophobia has rapidly spread over Europe and refugees have become the number one security enemy. Political leaders across Central and Eastern Europe have openly spoken against Muslim immigrants and Islam in general. Czech President Milos Zeman described the influx of refugee as "an invasion, organized by thousands of people smugglers," adding that the refugees are "Islamists who are coming to subjugate Europe." (The immigrants are islamists, 2015) Slovakia`s Prime Minister expressed resentment toward Muslim refugees saying that "Islam has no place in Slovakia." (Matharu, 2016) Moreover, Slovakia has banned Islam from the official list of state religions. This country has a small Muslim community, around 2,000 Muslim people, but there are no registered mosques. (Samuels, 2016) With no place to practice their religion and with hostile anti-Islam official policy, many refugees avoid seeking asylum here. Hungarian Prime Minister has recently depicted refugees as „Muslim invaders” and continues to advocate against immigration in the EU. (Schultheis, 2018) In Bulgaria anti-Muslim hate incidents are on the rise. Only in the first half of 2017 there were three recorded acts of vandalism targeting mosques and sites of worships across Bulgaria. (Muslim denomination in Bulgaria, 2017) It seems that the CEE countries are still not ready for multicultural and religious tolerant environment, rather they prefer culturally homogenous, purely ethnical and, if possible, anti-Muslim societies.

It is more likely that immigrants would feel less free to express their cultural and religious customs and suffer greatly from social isolation in a more xenophobic society. Majority of migrants from the Middle East and North Africa are running from political conflicts and economic poverty, they do not consider their cultural or religious identities as an issue and thus not something that is open for change. Moreover, newcomers also feel more comfortable in a country with already established familiar minority communities close to their own cultural affiliation. That is probably why Germany with more open immigration policy, huge experience in accommodating newcomers and established Muslim communities might be more attractive to the Middle Eastern and North African immigrants than any of the Central or Eastern European societies.

\section{Concluding remarks}

Poor immigrant integration in the CEE region has exposed a multidimensional nature of migration issue. Political, economic and social reasons are all responsible for less 
successful integration of newcomers in Central and Easter European societies. However, blame is not only on the countries ' unsuitable immigration policies and wide spread anti-immigrant sentiments but also on the unwillingness of refugees to adapt into new environment. Political factors depict an alarming rise of the far-right and populist parties across the region but also refugees reluctance to apply for asylum in CEE which poses a great obstacle to fruitful societal integration. In the economic sphere, lower economic productivity, lack of job opportunities and lower standard of living compared to the Western economies are reasons which discourage many migrants to even consider the CEE countries as a promising settling destination. Additionally, the CEE region has to deal with its own emigration problem and how to create more effective national strategies to prevent citizens from leaving. Preoccupation over their own economic poverty and political instability has made Central-East Europe less interested in the integration of newcomers. Finally, at the social level, reasons such as not having enough experience with different cultures due to decades of long communist rule and the need for restoration of its own cultural and religious identities have made the region more hostile and closed-minded towards alien cultural and religious practices. On the other hand, the Middle Eastern and North African migrants are attracted by more tolerant and multicultural societies of the Western Europe, which further complicates the process of successful immigrant integration in the Central and Eastern European societies.

\section{References:}

Asylum and first time asylum applicants by citizenship, age and sex Annual aggregated data (rounded), Eurostat, updated March 3, (2019), Accessed: March 18, 2019. Available at: http://appsso. eurostat.ec.europa.eu/nui/show.do?query=BOOKMARK_DS-057066_QID_-5E3D44D7 _UID_-3F171EB0\&layout=TIME,C,X,0;GEO,L,Y,0;CITIZEN,L,Z,0;SEX,L,Z,1;AGE,L,Z,2; ASYL_APP,L,Z,3;UNIT,L,Z,4;INDICATORS,C,Z,5;\&zSelection=DS-057066CITIZEN, EXT_EU28;DS-057066UNIT,PER;DS-057066ASYL_APP,NASY_APP;DS-057066 INDICATORS,OBS_FLAG;DS-057066SEX,T;DS-057066AGE,TOTAL;\&rankName1= UNIT_1_2_-1_2\&rankName2=AGE_1_2_-1_2\&rankName3=CITIZEN_1_2_-1_2\&rank Name4=INDICATORS_1_2_-1_2\&rankName5=ASYL-APP_1_2_-1_2\&rankName6= SEX_1_2_1_2\&rankName7=TIME_1_0_0_0\&rankName8=GEO_1_2_0_1\&sortC=ASC_1_FIRST $\& \mathrm{rStp}=\& \mathrm{cStp}=\& \mathrm{rDCh}=\& \mathrm{cDCh}=\& \mathrm{rDM}=$ true $\& \mathrm{cDM}=$ true $\&$ footnes $=$ false\&empty $=$ false\&wai=false\&time_mode $=$ ROLLING\&time_most_recent $=$ true\&lang $=E N \& c f o=\% 23 \% 23$ $\% 23 \% 2 \mathrm{C} \% 23 \% 23 \% 23 . \% 23 \% 23 \% 23$

Aisch, G., Pearce, A. \& Rousseau, B., (2016), How far is Europe swinging to the right? The New York Times, Accessed: July 18, 2018. Available at: http://www.nytimes.com/interactive/2016/05/ 22/world/europe/europe-right-wing-austria-hungary.html.

"Czech President Miloš Zeman: The immigrants are islamists. They are trying to subjugate Europe", (2015), Britské listy. Accessed: August 25, 2018. Available at: http://blisty.cz/art/79737.html .

Fischer, R., (2018), Average Salary in European Union 2018. Reinis Fischer. Accessed: August 25, 2018. Available at: https://www.reinisfischer.com/average-salary-european-union-2018.

Holleran, M., (2018), The opportunities rise for Europe's far right. New Republic. Accessed: August 16, 2018. Available at: https://newrepublic.com/article/147102/opportunistic-rise-europes-farright. 
Horn, H., (2015), Is Eastern Europe More Xenophobic Than Western Europe? Investigating A Stereotype Of The Refugee Crisis. The Atlantic. Accessed: August 17, 2018. Available at: http://www.theatlantic.com/international/archive/2015/10/xenophobia-eastern-europerefugees $/ 410800 /$.

"Hungary and Slovakia back tough stance on migrants.", (2018), Euronews. Accessed: August 20, 2018. Available at: http://www.euronews.com/2018/06/12/hungary-and-slovakia-back-toughstance-on-migrants.

Krastev, I., (2015), Eastern Europe's Compassion Deficit. The New York Times. Accessed: August 11, 2018. Available at: https://www.nytimes.com/2015/09/09/opinion/eastern-europescompassion-deficit-refugees-migrants.html.

Matharu, H., (2016), Slovakian Prime Minister says 'Islam has no place in this country' - weeks before it takes over EU presidency. The Independent. Accessed: August 25, 2018. Available at: https://www.independent.co.uk/news/world/europe/islam-has-no-place-in-this-country-saysslovakian-prime-minister-weeks-before-it-takes-over-eu-a 7052506.html.

Muller, R. \& Hovet, J., (2018), Czech President Zeman Re-Elected With Anti-Immigration Message. Reuters. Accessed: August 14, 2018. Available at: https://www.reuters.com/article/us-czechelection-president/czech-president-zeman-re-elected-with-anti-immigration-messageidUSKBN1FG00C.

"Musli m Denomination in Bulgaria", (2017), The Office of the Grand Mufti in Bulgaria. Available at: https://www.osce.org/odihr/325336?download=true.

"Religious Belief and National Belonging in Central and Eastern Europe.", (2017), Pew Research Center. Accessed: August 15, 2018. Available at: http://www.pewforum.org/2017/05/10/ religious-belief-and-national-belonging-in-central-and-eastern-europe/\#fnref-27936-5.

Schultheis, E., Viktor Orbán: (2018) Hungary doesn’t want „Muslim invaders'. POLITICO. Accessed: August 25, 2018. Available at: https://www.politico.eu/article/viktor-orban-hungary-doesntwant-muslim-invaders/.

Schweitzer, A., 2015, Eastern Europe's Hard Attitude to Refugees is Born out of Trauma. The Guardian. Accessed: August 17, 2018. Available at: http://www.theguardian.com/world/ commentisfree/2015/oct/22/refugee-eastern-europe-trauma-governments-bigotry.

Parikh, T., (2017), The EU's Other Migration Problem. Brain Drain in Central and Eastern Europe. Foreign Affairs. Accessed: August 25, 2018. Available at: https://www.foreignaffairs.com/ articles/centraleurope/2017-03-30/eus-other-migration-problem.

Podgorzanska, R., (2017), The Migration Crisis from the East-Central European Perspective: Challenges for Regional Security. Polish Political Science Yearbook. Vol. 46 (2) pp. 87-104. DOI:10.15804/ppsy2017206P

Postelnicescu, C., (2016), Europe's New Identity: e Refugee Crisis and the Rise of Nationalism. Europe's Journal of Psychology 12(2): 203. doi:10.5964/ejop.v12i2.1191

Van der Veer, K., Ommundsen, R., Yakushko, O., \& Higler, L., (2011), Cross-national measure of fear-based xenophobia: Development of a cumulative scale. Psychological Reports, 109(1), 2742. doi: 10.2466/07.17.PR0.109.4.27-42.

Waldie, P. (2018). What happened to Poland? How Poles drifted from Europe into populist authoritarianism. The Globe and Mail. Accessed: August 20, 2018. Available at: https://www.theglobeandmail.com/news/world/what-happened-

topoland/article37717930/\#index. 